\title{
HUBUNGAN ANTARA JARAK SEPTIC TANK KE SUMUR GALI DAN KANDUNGAN ESCHERICHIA COLI DALAM AIR SUMUR GALI DI KELURAHAN TUMINTING KECAMATAN TUMINTING KOTA MANADO
}

\author{
Margareth R. Sapulete \\ Bagian Ilmu Kesehatan Masyarakat \\ Fakultas Kedokteran Universitas Sam Ratulangi Manado \\ Email: margarethsapulete@yahoo.com
}

\begin{abstract}
Water is a vital requirement for all living creatures. Standards for monitoring drinking water and clean water for other uses are rare. Besides that, water sources such as wells are contaminated by many pollutants. According to the laboratory results conducted by the Tuminting Public Health Centre, wells used in the Tuminting District, Manado, have experienced $E$. coli contamination. The aim of this research was to identify factors associated with $E$. coli in the water of wells in the Tuminting District. The method used in this research was descriptive analysis. Through interviews and checklists of wells' owners, primary data were collected and then laboratory examinations of well-water samples were carried out. Secondary data were collected from the Health Department of Manado, and the Health Centre and the District Office of Tuminting. We used 30 water samples by simple random sampling of 67 wells. Data were analyzed through univariate and bivariate correlation tests. The results showed that $E$. coli in well water used by the public in the Tuminting District exceeded the standard of clean water according to the Regulations of the Ministry of Health Republic of Indonesia No.416/MENKES/PER/IX/1990 and of drinking water according to the Decree of Health Ministry No. 907/MENKES/SK/VII/2002. Moreover, there was a significant relationship between the distance of wells to septic tanks and the E. coli contents in well water. We suggest that the government improve the construction of wells and septic tanks, provide qualified water supply, and introduce the usage of chlorine to achieve clean water and a better all round health status for the Tuminting public.
\end{abstract}

Keywords: water, wells, $E$ coli, septic tank

\begin{abstract}
Abstrak: Air merupakan kebutuhan vital bagi semua mahluk hidup. Standar monitoring air minum maupun untuk penggunaan lainnya masih jarang. Selain itu, sumber air seperti sumur telah dicemari oleh berbagai polutan. Hasil pemeriksaan laboratorium yang dilaksanakan oleh Puskesmas Tuminting menunjukkan bahwa sumur gali di kelurahan Tuminting telah tercemar Esherichia coli. Tujuan penelitian untuk mendapatkan faktor-faktor yang berperan terhadap pencemaran E. coli dalam air sumur kelurahan Tuminting. Metode penelitian yang digunakan yaitu deskriptif analitik. Data primer dikumpulkan melalui wawancara dengan pemilik sumur gali dengan menggunakan check list, dilanjutkan dengan pemeriksaan laboratorium terhadap sampel air sumur gali. Data sekunder diambil dari Dinas Kesehatan Kota Manado serta Puskesmas Tuminting dan Kantor Kelurahan Tuminting. Sampel ditentukan dengan metode simple random dan diperoleh 30 sampel air dari 67 sumur gali. Data dianalisis secara univariat dan bivariat dengan menggunakan uji korelasi. Hasil penelitian menunjukkan bahwa kandungan $E$. coli dalam air sumur gali yang digunakan oleh masyarakat di Kelurahan Tuminting melebihi standar baku mutu air bersih sesuai dengan Peraturan Menteri Kesehatan RI Nomor 416/MENKES/PER/IX/1990 maupun dari air minum sesuai dengan Keputusan Menteri Kesehatan RI Nomor 907/MENKES/SK/VII/2002. Selain
\end{abstract}


itu terdapat hubungan yang bermakna antara jarak sumur gali ke septic tank dan kandungan $E$. Coli dalam air sumur gali. Disarankan kepada pihak pemerintah daerah untuk melakukan perbaikan konstruksi sumur gali maupun septic tank, menyediakan air bersih yang memenuhi syarat kesehatan, dan sosialisasi kepada masyarakat tentang penggunaan air bersih dan kaporisasi.

Kata kunci: air, sumur gali, E. coli, septic tank

Air yang kita gunakan sehari-hari merupakan suatu kebutuhan yang sangat vital baik sebagai pencuci maupun sebagai air minum. Oleh karenanya jelaslah, air yang akan kita gunakan untuk kedua maksud tersebut haruslah berkualitas sesuai dengan standar pengawasan yang telah ditetapkan oleh yang berwenang. Kenyataan di lapangan berbicara lain. Air bersih semakin langka, terutama yang berasal dari sumber air sumur gali telah tercemar. Contohnya sumber air sumur gali yang digunakan oleh masyarakat yang ada di kelurahan Tuminting kecamatan Tuminting kota Manado telah mengalami pencemaran E. Coli menurut pemeriksaan laboratorium Puskesmas Tuminting.

Kelurahan Tuminting merupakan salah satu kelurahan di kecamatan Tuminting kota Manado, dengan jumlah penduduk 6931 jiwa atau 1765 kepala keluarga (KK). Tercatat kepemilikam sumber air bersih yaitu perpipaan yang berasal dari PT. Air sebanyak 783 KK (pemilik) digunakan oleh $971 \mathrm{KK}(55 \%)$; sumur gali 110 buah, tetapi yang digunakan sebagai sumber air minum, memasak, mencuci sebanyak 67 buah oleh 293 KK (17\%); sumur bor 210 buah digunakan oleh $391 \mathrm{KK}(22 \%)$, sumber air dari tiga mata air digunakan oleh $110 \mathrm{KK}$ $(6 \%)$.

Salah satu penyebab tercemarnya sumber air sumur, yang digunakan untuk segala macam kebutuhan pembersih dan air minum tersebut, adalah jaraknya dengan septic tank tidak memenuhi syarat-syarat kesehatan seperti yang telah ditentukan. Air yang tercemar bila digunakan terutama untuk kebutuhan minum jelas akan mempengaruhi status kesehatan individu maupun masyarakat umum. Hal ini disebabkan air yang telah tercemar tersebut dapat menimbulkan berbagai macam penyakit pada yang menggunakannya, baik penyakit infeksi maupun penyakit non-infeksi. Pada gilirannya nanti, sektor yang lain seperti ekonomi, sosial, budaya dan lain-lain akan ikut terganggu, sehingga pembangunan nasional secara umum akan ikut terpengaruh.

Menurut data sekunder dari Puskesmas Tuminting bulan Januari s/d Desember 2009 terdapat 936 kasus diare. Sekalipun demikian masih perlu dilakukan penelitian lebih lanjut tentang penyebab kasus diare tersebut. Kasus diare ini termasuk dalam 10 penyakit menonjol yang tercatat di Puskesmas Tuminting. Penyebaran penyakit diare yang cukup tinggi di masyarakat dapat diakibatkan berbagai faktor diantaranya karena kualitas air yang tidak memenuhi syarat kesehatan.

Berdasar pemikiran-pemikiran yang mengemuka di atas itulah yang mendorong penulis melakukan penelitian ini dengan tujuan untuk mengetahui apakah terdapat hubungan di antara jarak septic tank dengan sumur gali berkaitan dengan banyaknya kandungan E. Coli dalam air sumur gali tersebut di kelurahan Tuminting kota Manado.

\section{TINJAUAN PUSTAKA}

Pembangunan kesehatan adalah upaya yang dilaksanakan oleh semua komponen bangsa yang bertujuan untuk meningkatkan kesadaran, kemauan dan kemampuan hidup sehat bagi setiap orang agar derajat kesehatan yang tinggi dapat terwujud. Penyelenggaraan pembangunan kesehatan tersebut harus dilakukan dengan cermat sebab masalah kesehatan merupakan suatu masalah yang sangat kompleks, yang saling berkaitan dengan masalah-masalah lain di luar masalah kesehatan itu sendiri. Terdapat empat faktor yang memengaruhi status kesehatan masyarakat, yaitu faktor lingkung- 
an, perilaku, pelayanan kesehatan, dan herediter. ${ }^{1}$

Lingkungan merupakan salah satu faktor yang menentukan derajat kesehatan masyarakat yang optimal karena lingkungan dapat memengaruhi kesehatan masyarakat. Salah satu upaya peningkatan kesejahteraan masyarakat khususnya dalam bidang kesehatan lingkungan yakni pembangunan dan pengawasan terhadap kualitas air. Air secara langsung maupun tidak langsung dapat menyebabkan berbagai jenis penyakit baik penyakit infeksi maupun penyakit non infeksi. Jadi, air merupakan sarana utama untuk meningkatkan derajat kesehatan masyarakat, yakni sebagai sumber air bersih dan sumber air minum. ${ }^{2}$

Air yang berkualitas baik adalah air yang memenuhi standar kualitas air di Indonesia yang telah ditetapkan melalui peraturan menteri kesehatan RI nomor 416/MENKES/PER/IX/1990 tentang syaratsyarat dan pengawasan kualitas air bersih, dan keputusan menteri kesehatan RI Nomor 907/MENKES/SK/VII/2002 tentang syaratsyarat dan pengawasan kualitas air minum. Dalam peraturan tersebut dijelaskan bahwa air bersih dan air minum harus memenuhi syarat kesehatan baik fisik, kimia, mikrobiologi dan syarat radioaktif. ${ }^{2}$

Dalam Kepmenkes RI Nomor 907/ MENKES/SK/VII/2002 tersebut dijelaskan bahwa, air yang dapat digunakan sebagai air minum yaitu jika dalam 100 mililiter $(\mathrm{ml})$ air, coliform tinja harus nihil. Untuk air bersih ditetapkan dalam Peraturan Menteri Kesehatan No. 416 Tahun 1990 tentang syarat-syarat dan pengawasan kualitas air bersih yang menjelaskan bahwa total coliform dan coliform tinja harus $0 / 100 \mathrm{ml}$ air pada air yang bukan perpipaan. ${ }^{3}$

Escherichia coli (E. coli) merupakan bakteri coliform yang secara normal terdapat di dalam kotoran manusia atau pun hewan. E. coli digunakan sebagai indikator untuk menilai tentang baik tidaknya persediaan air untuk keperluan rumah tangga dan industri makanan. Jadi dikatakan air telah tercemar dengan feses, apabila air yang akan digunakan tersebut telah mengandung E. coli. Sedangkan air yang telah tercemar dengan feses dapat menimbulkan berbagai macam penyakit pencernaan seperti kolera, tifus, disentri, cacingan dan lain-lain dengan gejala diare. Dalam 1 gram faeces bisa terdapat sekitar 100 juta E. coli. Keberadaan E. coli di air dipengaruhi oleh banyak hal yakni konstruksi fisik sumur, baik dinding sumur, bibir sumur, lantai sumur, dan sarana pembuangan air limbah, serta jarak septic tank dengan sumur gali yang kurang dari 11 meter. ${ }^{4}$

Penelitian tentang hubungan jarak septic tank dengan jumlah kandungan bakteri $E$. coli pada air sumur gali di kabupaten Tegal telah membuktikan bahwa jarak septic tank memberikan sumbangan $44 \%$ terhadap kandungan bakteri $E$. coli dalam air sumur gali. Jarak jangkau pencemaran tanah oleh bakteri secara horizontal yaitu 11 meter, dan vertikal yaitu 2 meter. Hal ini penting diketahui untuk mencegah tecemarnya air oleh tempat pembuangan kotoran atau tinja. Berdasarkan hasil penelitian tersebut, jelas terlihat bahwa semakin dekat jarak septic tank dengan sumur gali, maka semakin besar pula kandungan bakteri yang terdapat didalamnya. ${ }^{5-7}$

Air merupakan senyawa kimia yang sangat penting bagi kehidupan makhluk di bumi ini karena merupakan kebutuhan utama bagi proses kehidupan biologis. Selain itu air yang relatif bersih, yang digunakan untuk kebutuhan mencuci seharihari, juga bagi keperluan industri, kebersihan sanitasi didaerah permukiman, maupun untuk keperluan pertanian dan lain sebagainya. $^{8}$

Fungsi air bagi kehidupan tidak dapat digantikan oleh senyawa lain. Pada orang dewasa sekitar 55-60\% berat badannya terdiri atas air, anak-anak sekitar 65\%, sedangkan bayi sekitar $80 \%$. Dalam tubuh manusia air juga diperlukan untuk melarutkan berbagai jenis zat. Penggunaan air yang utama dan sangat vital bagi kehidupan yakni sebagai sumber air bersih dan sumber air minum, oleh karena itu kualitasnya harus memenuhi syarat kesehatan. Sumber air minum di Indonesia umumnya berasal dari air permukaan (surface water), air tanah (ground water) dan air hujan. ${ }^{9,10}$ 
Keputusan Menteri Kesehatan Republik Indonesia (Kepmenkes RI) Nomor 907/Menkes/SK/VII/2002 tentang syaratsyarat dan pengawasan kualitas air minum adalah sebagai berikut: ${ }^{11}$

1. Syarat mikrobiologis.

E. coli merupakan parameter dalam penilaian persyaratan kualitas air minum. Kadar maksimum dalam air minum yang diizinkankan yaitu " 0 ". Air minum harus bebas dari kuman-kuman penyakit, termasuk didalamnya bakteri, protozoa, virus, cacing dan jamur.

2. Syarat kimia

Tidak diperbolehkan mengandung zat kimia (misalnya pestisida, desinfektans dan hasil sampingannya) dalam kadar yang melebihi kadar maksimum yang telah ditetapkan, karena dapat mengganggu kesehatan. Air harus bebas dari unsur kimia beracun, baik itu anorganik maupun organik.

3. Syarat radioaktif

Tidak terdapat unsur-unsur radioaktif didalam air seperti sinar alfa. Sinar ini tidak mempunyai daya tembus sehingga efek yang terjadi biasanya bersifat lokal dan apabila tertelan lewat minuman dapat merusakkan sel-sel saluran pencernaan. Sinar beta mempunyai daya tembus yang besar sehingga sinar ini dapat menembus kulit yang dapat mengakibatkan kerusakan organ tubuh.

4. Syarat fisik

Syarat-syarat fisik yaitu suhu 10$15^{0} \mathrm{C}$, bebas bau, tidak terasa, tidak berwarna, tidak keruh, dan jumlah zat padat terlarut yang bisa terdapat dalam air adalah 500-1500 mg/L.

Sumur gali merupakan salah satu sarana penyediaan air bersih. Sumur dibuat dengan cara menggali tanah sampai mendapatkan lapisan air dengan kedalaman tertentu. Sumur terdiri dari bibir sumur, dinding sumur, lantai sumur, saluran air limbah, dan dilengkapi kerekan timba dengan tali atau menggunakan pompa. ${ }^{12}$

Sumur yang baik harus memenuhi syarat lokasi yaitu jaraknya tidak kurang dari 11 meter dan letaknya diusahakan tidak berada dibawah tempat-tempat sumber pengotoran seperti kakus, empang, lubang galian untuk air kotor dan sebagainya. ${ }^{5}$

Sumur gali dengan kedalaman 15 meter layak digunakan sebagai sumber air minum oleh karena kualitas air tanah dalam umumnya lebih sempurna dan bebas bakteri. Kehidupan bakteri golongan patogen maupun tidak patogen didasari pada keadaan lingkungan sekitarnya; tergantung ada tidaknya oksigen $\left(\mathrm{O}_{2}\right)$. Dengan adanya oksigen, mikroorganisme dapat melakukan proses aerobik sehingga dapat mengembangkan kehidupannya dengan memanfaatkan lingkungan sekitarnya. ${ }^{13}$

E. coli merupakan salah satu jenis spesies utama bakteri gram negatif. Bakteri ini ditemukan oleh Theodor Escherich pada tahun 1885 dari kotoran bayi. E. coli yang hidup dan merupakan spesies dominan dalam tinja dapat menyebabkan diare, muntahberak (muntaber) dan masalah pencernaan lainnya. Bakteri ini banyak digunakan dalam teknologi rekayasa genetika; biasa digunakan sebagai vektor untuk menyisipkan gen-gen tertentu yang diinginkan untuk dikembangkan. E. coli dipilih karena pertumbuhannya sangat cepat dan mudah dalam penanganannya. Bakteri ini hidup dalam jumlah besar di dalam usus manusia dan hewan, yaitu membantu sistem pencernaan manusia dan melindunginya dari bakteri patogen. Akan tetapi ada strain baru $E$. coli yang berbahaya karena bersifat patogen. E. Coli mempunyai dimensi berbentuk batang pendek gemuk dengan panjang 1-3 $\mu \mathrm{m}$ dan lebar $0,4-0,7 \mu \mathrm{m}$, gram negatif bergerak aktif dan tidak berspora. ${ }^{14}$

E. coli dapat tumbuh pada suhu $10^{\circ} \mathrm{C}$ $40^{\circ} \mathrm{C}$ dengan suhu optimal $37^{\circ} \mathrm{C}$. Pertumbuhan optimal terjadi pada $\mathrm{pH} 7,0$ 7,5 (kisaran $\mathrm{pH}$ : 4,0 - 9.0). Bakteri ini sangat peka terhadap panas dan dapat diinaktifkan pada suhu pasteurisasi makanan atau selama pemasakan. E. coli dapat tahan berbulan-bulan dalam tanah dan di dalam air, tetapi dapat dimatikan dengan pemanasan pada $60^{\circ} \mathrm{C}$ selama 20 menit atau jika diberi klorin berkadar 0,5 sampai 1 part per million (ppm). ${ }^{16}$ 


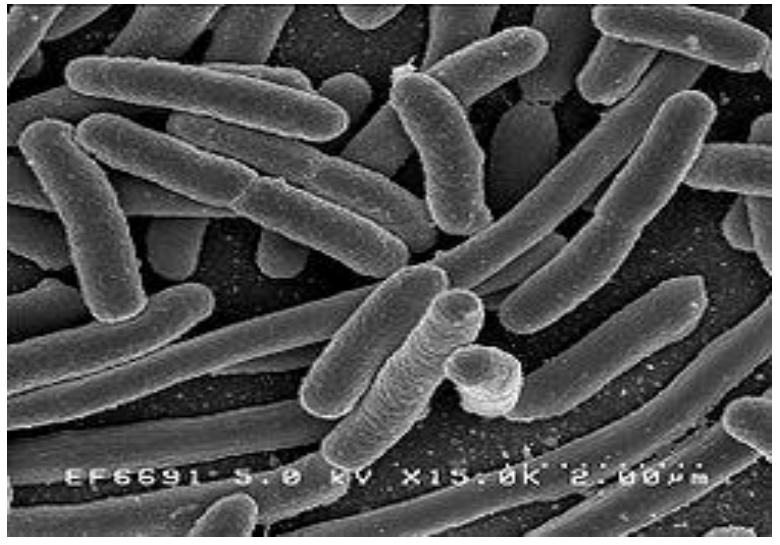

Gambar 1. Mikrofoto E. Coli. Sumber: Rocky Mountain Laboratories. ${ }^{15}$

E. coli dapat tumbuh pada suhu $10^{\circ} \mathrm{C}$ $40^{\circ} \mathrm{C}$ dengan suhu optimal $37^{\circ} \mathrm{C}$. Pertumbuhan optimal terjadi pada $\mathrm{pH} 7,0-7,5$ (kisaran $\mathrm{pH}: 4,0-9.0$ ). Bakteri ini sangat peka terhadap panas dan dapat diinaktifkan pada suhu pasteurisasi makanan atau selama pemasakan. E. coli dapat tahan berbulanbulan dalam tanah dan di dalam air, tetapi dapat dimatikan dengan pemanasan pada $60^{\circ} \mathrm{C}$ selama 20 menit atau jika diberi klorin berkadar 0,5 sampai 1 part per million (ppm). ${ }^{16}$

\section{HIPOTESIS}

Terdapat hubungan yang bermakna di antara jumlah $E$. coli dalam air sumur gali dengan jarak sumur gali ke septic tank.

\section{METODE PENELITIAN}

Penelitian ini dilaksanakan di kelurahan Tuminting kecamatan Tuminting kota Manado pada bulan Februari-April 2010.
Sampel yang digunakan yaitu air sumur gali. Penelitian ini merupakan penelitian analitik. Data yang dikumpulkan yaitu jumlah E. coli pada air sumur gali dan jarak septic tank ke sumur gali.

Untuk mengetahui hubungan jarak maupun konstruksi sumur gali dengan kandungan E. coli, dibuat klasifikasi berdasarkan jumlah yakni <1000 MPN, 1000-2000 MPN dan >2000 MPN.

\section{HASIL PENELITIAN}

Sesuai klasifikasi metodologi penelitian yang telah ditentukan ini, diperoleh data bahwa sumur gali yang mengandung $E$. coli lebih dari 2000 MPN sebanyak delapan sumur gali (26\%), kurang dari $1000 \mathrm{MPN}$ 20 sumur gali $(67 \%)$ dan sebagaian kecil 1000- 2000 MPN dua sumur gali (7 \%).

Berdasarkan hasil observasi dan pengukuran terhadap jarak sumur gali dengan septic tank atau lubang penampungan kotoran dari 30 sumur gali sebagai sampel, diperoleh data seperti pada Tabel 1 .

Data pada Tabel 1 menggambarkan tentang jarak antara sumur gali dengan lubang penampungan kotoran dimana sebanyak $83 \%$ (25 buah sumur) memiliki jarak kurang dari 11 meter yang dikategorikan tidak memenuhi syarat kesehatan dan $17 \%$ (lima buah sumur) memiliki jarak lebih dari 11 meter yang dikategorikan memenuhi syarat kesehatan.

Data pada Tabel 1 menggambarkan tentang jarak antara sumur gali dengan lubang penampungan kotoran dimana sebanyak $83 \%$ ( 25 buah sumur) memiliki jarak kurang dari 11 meter yang dikategorikan tidak

Tabel 1. Distribusi kandungan E. coli menurut jarak septic tank dengan sumur gali di Kelurahan Tuminting Tahun 2010

\begin{tabular}{|c|c|c|c|c|c|c|c|c|}
\hline \multirow{2}{*}{ No } & \multirow{2}{*}{$\begin{array}{l}\text { Kandungan } \\
\text { E. coli }(M P N)\end{array}$} & \multicolumn{5}{|c|}{$\begin{array}{l}\text { Jarak sumur gali dengan septic tank/lobang } \\
\text { penampungan kotoran }\end{array}$} & \multirow{2}{*}{ Jlh } & \multirow{2}{*}{$\%$} \\
\hline & & $<11$ Meter & $\%$ & $\geq 11$ & Meter & $\%$ & & \\
\hline 1 & $<1000$ & 16 & 53 & & 4 & 14 & 20 & 67 \\
\hline 2 & $1000-2000$ & 2 & 7 & & 0 & 0 & 2 & 7 \\
\hline \multirow[t]{2}{*}{3} & $>2000$ & 7 & 23 & & 1 & 3 & 8 & 26 \\
\hline & Jumlah & 25 & 83 & & 5 & 17 & 30 & 100 \\
\hline
\end{tabular}


memenuhi syarat kesehatan dan $17 \%$ (lima buah sumur) memiliki jarak lebih dari 11 meter yang dikategorikan memenuhi syarat kesehatan.

Untuk mengetahui apakah terdapat hubungan yang bermakna antara jarak septic tank atau lubang penampungan kotoran serta konstruksi sumur gali dengan kandungan E. coli pada air sumur gali di kelurahan Tuminting, maka dilakukan uji statistik. Untuk memperjelas hubungan jarak septic tank dengan kandungan E. coli dalam air sumur gali di kelurahan Tuminting kota Manado Tahun 2010, dapat dilihat pada Gambar 2.

Gambar 2 memperlihatkan bahwa jarak sumur dengan lubang penampungan kotoran baik yang memenuhi syarat maupun tidak memenuhi syarat, semuanya mengandung E. coli. Untuk mengetahui apakah terdapat hubungan yang bermakna di antara jarak sumur dengan septic tank atau lubang penampungan kotoran serta konstruksi sumur gali dengan kandungan E. coli air sumur gali, maka dilakukan uji statistik. Hasil uji statistik dapat dilihat pada Tabel 2.

Dari hasil uji statistik dengan derajat kemaknaan $\alpha<0.05$, diperoleh hasil probabilitas $(p)=0.039$ yang berarti bahwa terdapat hubungan yang sangat bermakna secara statistik antara jarak sumur gali dengan septic tank atau lubang penampungan kotoran
Tabel 2. Hasil uji statistik Pearson Correlation

\begin{tabular}{lll}
\hline \multicolumn{1}{c}{$\begin{array}{c}\text { Variabel } \\
\text { Penelitian }\end{array}$} & \multicolumn{1}{c}{ Nilai p } & Kesimpulan \\
\hline Jarak & Pearson & $0,039<0,05$ \\
Sumur & Correlation & H1 diterima \\
& 0,602 & \\
& Sig. (1-tailed) & \\
& 0,039 & \\
& $\mathrm{~N} \quad 30$ & \\
\hline
\end{tabular}

dengan kandungan E. coli dalam air sumur gali di kelurahan Tuminting kota Manado tahun 2010.

\section{BAHASAN}

Hasil penelitian yang dilakukan terhadap 30 sampel air sumur gali yang ada di Kelurahan Tuminting menunjukkan bahwa secara keseluruhan kandungan E. coli air sumur gali di kelurahan Tuminting kota Manado melebihi standar baku mutu kualitas bakteriologis air minum mapun air bersih sebagaimana ditetapkan dalam Permenkes nomor 907/Menkes/SK/VII/ 2002 dan Permenkes nomor 416/MENKES/PER/ IX/1990 tentang syarat-syarat dan pengawasan kualitas air minum dan air bersih yaitu 0/100 ml sampel air. Hasil pemeriksaan kandungan $E$. coli pada 30 sampel air sumur gali berada sekitar 10

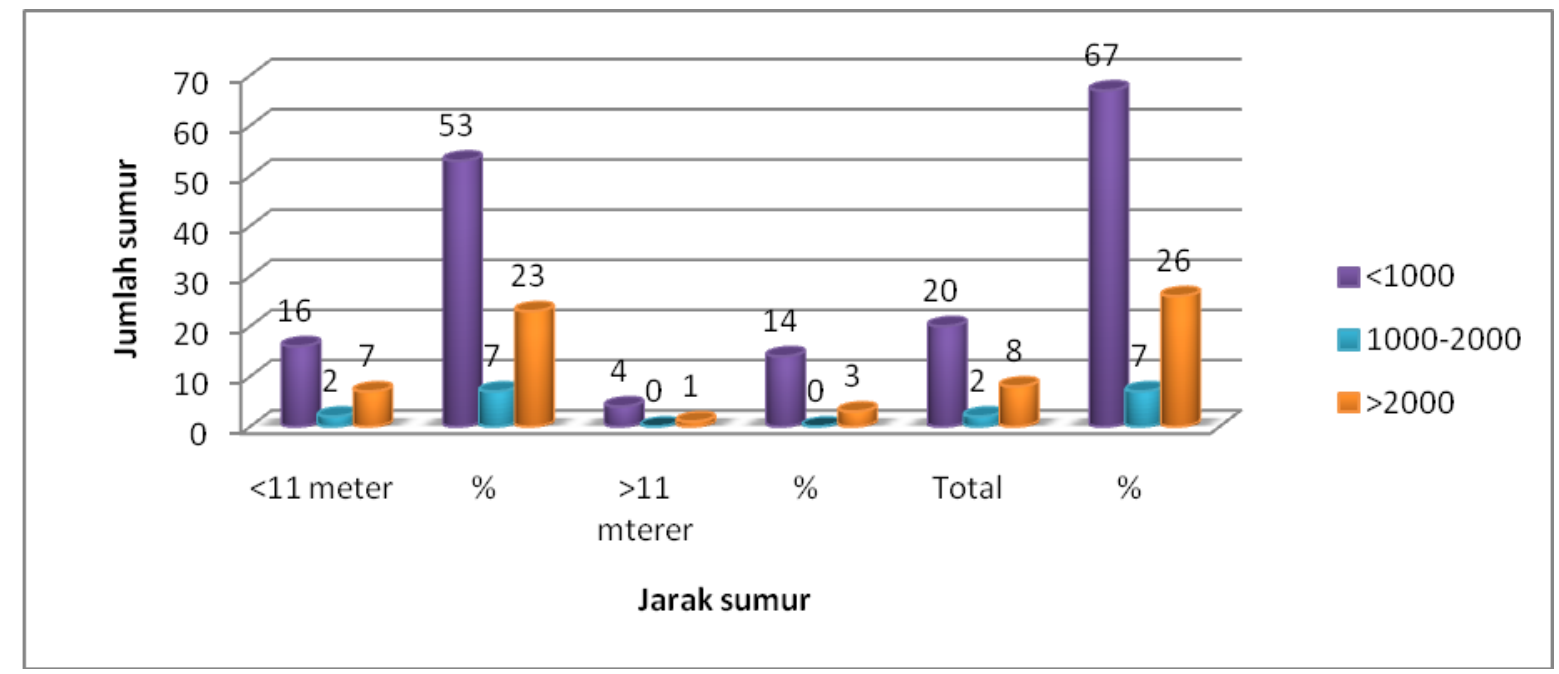

Gambar 2. Kondisi jarak dengan kandungan E. coli air sumur gali di kelurahan Tuminting kota Manado tahun 2010 
MPN/100ml air sampai dengan >2005 MPN/100 ml.

Pemeriksaan bakteri E. coli dalam sampel air di laboratorium merupakan suatu cara untuk menentukan baik tidaknya kualitas air berdasarkan parameter mikrobiologi. Berdasarkan surat keputusan Menkes R.I No: 907/ Menkes/SK/VII/2002 tentang syarat-syarat dan pengawasan kualitas air ainum dinyatakan bahwa, bila dalam sampel air ditemukan bakteri Coliform atau E. coli berarti air tersebut tidak memenuhi syarat sebagai air minum.

Dilihat dari hasil pengukuran terhadap jarak sumur gali dengan septic tank atau lubang penampungan kotoran diperoleh hasil yaitu $83 \%$ (25 buah sumur gali) berukuran kurang dari 11 meter dan mengandung E. coli jauh diatas nilai maksimum yang diperbolehkan, yaitu berkisar antara 10 MPN/100 ml air sampai dengan lebih dari 2005 MPN/100 ml air. Hasil penelitian ini sesuai dengan hasil penelitian yang dilakukan oleh Sarman terhadap air sumur gali yang ada di perumahan Wenang Permai II, Wale Lestari Indah dan Mapanget Raya yang menunjukan hasil bahwa semakin dekat jarak sumber pencemar dengan sumur gali maka jumlah Coliform dan E. coli semakin tinggi, yang berarti kualitas air sumurnya semakin rendah. Djabu menyarankan untuk jenis tanah liat sebaiknya jarak minimal septic tank ke sumber air bersih 15 meter. Berdasarkan hasil analisis statistik yang dilakukan bahwa terdapat hubungan yang sangat bermakna (pada $\alpha=0.05$; $\mathrm{p}=0.039)$ di antara jarak sumur dengan septic tank atau lubang penampungan kotoran dengan kandungan $E$. coli, bersesuaian dengan pernyataan yang terdapat dalam buku pedoman bidang studi pembuangan tinja dan air limbah pada institusi pendidikan dan sanitasi kesehatan lingkungan yang menjelaskan bahwa jarak jangkau pencemaran tanah oleh bakteri secara horisontal yakni 11 meter. ${ }^{17-20}$

Hasil penelitian terhadap jarak sumur gali dengan septic tank atau lubang penampungan kotoran yang memenuhi syarat kesehatan yaitu 11 meter atau lebih sebanyak 17\% (lima buah sumur gali), tetapi dari hasil pemeriksaan laboratorium terhadap kualitas bakteriologis, lima buah sumur gali tersebut juga mengandung $E$. coli yang melebihi kadar maksimum yang diperbolehkan.

Selain jarak septic tank dengan sumur gali, maka syarat lain yang harus dipenuhi untuk memperoleh air yang bersih (minum dan cuci) ialah struktur dinding (beton diplester) dan lantai sumur gali serta sistem pembuangan air limbah (SPAL). Tak kalah pentingnya ialah pengetahuan masyarakat tentang apa yang dimaksud dengan air bersih. Tidak terpenuhinya syarat-syarat tersebut akan merupakan jalan pintu masuknya cemaran seperti E. coli yang dapat mendatangkan penyakit. Soemadji menyatakan bahwa patokan untuk jarak sumber air dengan septic tank atau lubang penampungan kotoran di antara 11-15 meter, bukan berarti bahwa sumber air dijamin atau dipastikan tidak tercemar, tetapi masih ada faktorfaktor lain yang mungkin(seperti tersebut di atas) dapat menyebabkan turunnya kualitas air sumur gali. ${ }^{21}$

Secara keseluruhan sanitasi yang ada di Kelurahan Tuminting masih perlu diperbaiki dan mendapat pengawasan dari pemerintah. Tentu saja masih dibutuhkan penelitian yang lebih lanjut mengenai dampak lingkungan yang lain maupun perilaku masyarakat terhadap kualitas air bersih yang ada di Kelurahan Tuminting.

\section{SIMPULAN}

Berdasarkan hasil penelitian dan pembahasan, maka dapat ditarik kesimpulan yaitu :

1. Terdapat hubungan yang sangat bermakna di antara jumlah E. coli air sumur gali dengan jarak sumur gali ke septic tank, di kelurahan Tuminting kota Manado

2. Kandungan E. coli dalam air sumur gali di kelurahan Tuminting kota Manado dalam pemenelitian ini melebihi kadar maksimum yang telah ditetapkan oleh pemerintah melalui peraturan Menteri Kesehatan RI nomor 416/MENKES/ PER/IX/1990 tentang syarat-syarat dan 
pengawasan kualitas air bersih dan keputusan Menteri Kesehatan RI nomor 907/MENKES/SK/VII/2002 tentang syarat-syarat dan pengawasan kualitas air minum.

\section{SARAN}

1. Perlu dilakukan terus menerus sosialisasi ataupun penyuluhan tentang pembuatan dan penggunaan sumur gali kepada masyarakat oleh dinas kesehatan dalam hal ini Puskesmas. Air yang akan digunakan untuk keperluan minum, agar terlebih dahulu dimasak sampai mendidih.

2. Di pasar tradisional Tuminting perlu dilakukan pengelolaan limbah bahan organik dan anorganik.

\section{DAFTAR PUSTAKA}

1. Indikator Indonesia Sehat 2010. Jakarta: Departemen Kesehatan RI; 2003.

2. Mulia R. Kesehatan Lingkungan. Yogyakarta: Graha Ilmu, 2005.

3. Peraturan Menteri Kesehatan RI No.907/ MENKES/ PER/ IX/2002 tentang syarat dan pengawasan kualitas air minum. Jakarta: Departemen Kesehatan RI; 2002.

4. Soemirat JS. Kesehatan Lingkungan Jurusan Teknik Lingkungan. Bandung: Institut Teknologi Bandung, 1994.

5. Arief S. Hubungan jarak septic tank terhadap jumlah kandungan bakteri Escherichia coli dalam air sumur gali di Desa Bukateja Kecamatan Balapulang Kabupaten Tegal (online). 2000 [cited 2009 Jan 27]. Available from: http/gdlli@litbang.depkes.selpro.net

6. Modul 4. Pelatihan kader kesehatan lingkungan. Direktorat Jenderal Pemberantasan Penyakit Menular dan Penyehatan Lingkungan. Jakarta: Departemen Kesehatan RI; 1993.

7. Entjang I. Ilmu Kesehatan Masyarakat. Bandung: Citra Aditya Bakti, 1993.
8. Anwar D. Pencemaran air dan dampaknya terhadap kesehatan. Makassar: Fakultas Kesehatan Masyarakat Universitas Hasanudin; 2002.

9. Notoadmodjo S. Ilmu Kesehatan Masyarakat: Prinsip-prinsip Dasar. Jakarta: Rineka Cipta, 2003.

10. Profil Kelurahan Tuminting 2009. Manado: Pemerintah Kota Manado; 2009.

11. Sistem Kesehatan Nasional. Jakarta: Departemen Kesehatan RI; 2004.

12. Penyediaan Air Bersih (PAB). Makassar: Jurusan Kesehatan Lingkungan, FKM UNHAS; 2001.

13. Totok S. Teknologi penyehatan air bersih. Jakarta: Rineka Cipta, 1987.

14. Waluyo L. Mikrobiologi Lingkungan. Jakarta: UMM Press, 2005.

15. Rocky Mountain Laboratories, National Institutes of Health, United States Department of Health and Human Services. [cited 2009 Jan 27]. Available from: http://www.niaid.nih.gov/topics/biodefen serelated/biodefense/publicmedia/pages/i mage_library.aspx

16. Julie A. Relative nephroprotection during Escherichia coli 0157: H7 infections: Association with intravenous volume expansion. Washington: Edward Mallinckrodt Department of Pediatric and Department of Molecular Microbiology Washington University School of Medicine; 2005.

17. Sarman. Analisis faktor kualitas bakteriologis air sumur gali perumahan di Kota Manado. Manado: Program Pascasarjana Universitas Sam Ratulangi; 2003.

18. Suharjo. Pembuatan limbah cair rumah tangga. Yogyakarta: Program Pascasarjana Universitas Gajahmada; 1998.

19. Djab U. Pembuangan tinja dan air limbah pada industri. Pendidikan Tenaga Kesehatan Lingkungan. Jakarta, 1992.

20. Kesehatan Lingkungan. Yogyakarta: Gajah Mada University; 2002.

21. Soemadji J. Pembuangan air kotoran dan air limbah. Pusat Pendidikan Tenaga Kesehatan Departemen Kesehatan RI. Jakarta, 1992 